\title{
Lindquist, Lisa J. (1995): Images of Alice: Gender, deviancy, and a love murder in Memphis, journal of the History of Sexuality, 6(1):30-61
}

resumo e comentários por Oswaldo M. Rodrigues $\mathrm{Jr}^{1}$

A autora discute uma situação de assassinato seguida do julgamento da homicida no ano de 1892. Alice Mitchell matou uma mulher porque a amava. $\mathrm{O}$ fato principal residiu na transgressão de uma multiplicidade de limites da mulher classe média e os comportamentos femininos aceitáveis da época.

A professora do departamento de história da Universidade de Virginia propõe compreender o fato através dos conceitos de masculinidade e feminilidade, racionalidade e sexualidade que tiveram mudanças importantes no início do século XX. Lindquist considera que a morte de Freda Ward, embora tivesse uma motivação do mesmo sexo, deveria ser definida como transgressão de gênero, uma violação de papéis de gênero mais do que transgressão sexual envolvendo atos imorais e tabu sexual.

O julgamento da sociedade vitoriana redefinira Alice de forma que a reintegrava à sociedade sem que ela continuasse desafiando a sociedade.

1. Psicólogo e Terapeuta Sexual associado ao Instituto H. Ellis (SP): Diretor de Publicações da sociedade Brasileira de sexualidade Humana (1995-97). 
A redefinição desarmou Alice, permitindo à sociedade em ignorar as implicações sexuais do comportamento dela e manter as idéias vitorianas sobre a sexualidade feminina.

Os jornais da época fizeram do caso um estardalhaço maior do que em outros homicídios da época. A referência era um "amor não natural". $\mathrm{O}$ desvio de Alice foi construído como violação dos limites do gênero e comportamento inapropriado ao gênero. Alice não apenas tentou agir igual a um homem, mas fez tentativas de exercer o papel masculino, algo nunca ouvido em moças de classe média! Querer casar-se com Frida era só uma parte.

Alice planejava abandonar a vida feminina, assumir uma identidade masculina, inclusive mudando vestimenta, encontrar um trabalho e casarse com uma mulher. Alice perverteu as idéias culturais aceitas sobre o amor a as relações amorosas, assim como os papéis sexuais masculinos e femininos.

O caso de Alice ficou lembrado pelo aspecto sexual, embora não tivesse acontecido nada fisicamente sexual e a despeito dos esforços do público e dos médicos em minimizar o aspecto sexual do homicida.

A caracterização de insanidade de Alice permitiu a reintegração dela à sociedade, transformando-a de monstro para uma moça calma, gentil e feminina, neutralizada pelos especialistas. A imagem apresentada pela mídia refletiu estas transformações. Internada em um hospício. Alice ficou restrita a reproduzir uma feminilidade repondo à sociedade os papéis de gênero considerados adequados à época e à região.

A autora demonstra a utilização de uma situação jurídica para manipulação ideológica objetivando controle moral social dos papéis de gênero. A mídia e os especialistas (médicos da cidade) são utilizados da mesma forma que a justiça, consolidando os papéis creditados a homens e Mulheres.

A autora desmascara os mecanismos sociais de controle ideológico, incluindo o uso dos representantes da ciência para caracterização e justificativa das ações no crime e em seu julgamento. 